\title{
Effect of Chelating Agents on Removal of Heavy Metal Cations of Cellulose-based Ion Exchange Resins from Water Hyacinth
}

\author{
Matcharee Suppapruek ${ }^{1}$, Poonsub Threepopnatkul ${ }^{1, *}$, Amnard Sittattrakul $^{1}$, and Wanchai Lerdwijitjarud ${ }^{1}$ \\ ${ }^{1}$ Department of Materials Science and Engineering, Faculty of Engineering and Industrial Technology, Silpakorn University, \\ Nakhon Pathom, 73000, Thailand
}

\begin{abstract}
Presently, heavy metal pollution in natural water resources is considered very hazardous. The purpose of this research is to develop the novel cellulose-based ion exchange resins from water hyacinth and the effect of chelating agents on the removal of heavy metal cations from single-metal aqueous solutions has been investigated. Cellulose was prepared from the stem of water hyacinth by alkaline treatment process then cellulose-based ion exchange resins were prepared via esterification reaction between cellulose with two different chelating agents such as pyromellitic dianhydride and 3,3',4,4'- benzophenone tetracarboxylic dianhydride. The chemical structure, crystallinity index, surface morphology, and thermal stability of resins were characterized and analyzed with FTIR, XRD, SEM, and TGA, respectively. The results confirmed the esterification reaction between anhydride groups of chelating agents with hydroxyl groups of celluloses due to the apparent peak of the ester group. Heavy metal cations adsorptions were studied in optimum conditions and the residual concentration of heavy metal cations was measured by ICP. These resins showed high adsorption capacities of more than $98 \mathrm{mg} / \mathrm{g}$ for $\mathrm{Pb}^{2+}, \mathrm{Cd}^{2+}, \mathrm{Cu}^{2+}$, and $\mathrm{Ni}^{2+}$. Moreover, the adsorption process was controlled by the ion exchange mechanism. Therefore, the novel cellulose-based ion exchange resins could be suitable for the removal of pollutants from wastewater.
\end{abstract}

Keyword. Water hyacinth, Ion exchange resins, Heavy metal cations adsorption, Chelating agent, Dianhydride

\section{Introduction}

Heavy metal has been continuously polluted the natural water resources from various sources: agriculture and the rapid development of industrialization and urbanization. To make the pictures clear; for example, here are those industries that may have caused the pollution: electroplating, steel production, metal foundry, battery and leather manufacturing, and nuclear power operation. However, these issues have become so critical due to the impact on the ecosystem, environment, living wellbeings, living organisms, and health hazards. These hazardous and adverse effects led to the necessity for the development of wastewater treatment methods for the removal of heavy metal cations from contaminated water to prevent these harmful consequences [1,2].

Presently, there are numerous ways of water treatment for metal ion removal from wastewater such as adsorption, chelation ion exchange, chemical precipitation, coagulation, flocculation, activated carbon, electrolytic methods, reverse osmosis, and membrane separation [3]. Chelation ion exchange is one of the superior physicochemical methods for heavy metal ion disposal in comparison with other methods because it has several advantages of high removal efficiency, low costs, no chemical sludge and easy accessibility. In addition, this method filtrates those harmless ions and releases them into the environment, while removes the toxic metal ions out. More importantly, chelation ion exchange means that chelating polymers and heavy metal ions are bonding with coordination bonds.

Ion exchange has been widely practiced in wastewater treatment industry. Despite some commercial ion exchange resin cost relatively lower than other wastewater treatment methods. It is still considered a hefty price tag when it comes to the actual bill. Most of these resins are not eco-friendly because of the nonbiodegradable matrix of the resins. Dowex $50 \mathrm{~W}$ and Amberlite IR-120 synthetic resins are commercial ion exchange resins. The structural polymeric backbone of the resins is styrene cross-linked with divinylbenzene functionalized with sulfonic acid, a functional group acted as ion exchange site $[4,5]$. Furthermore, there are other commercial ion exchange resins such as Dow XUS 43578, Diaion CR11, Dowex HCR W2, and Purolite C160 [6]. Each resin has different matrix and its own active group acting as the ion exchange site. Therefore, the task of developing an eco-friendly bio-based ion exchange resin yet efficient enough to eliminate the

* Corresponding author: threepopnatkul_p@su.ac.th 
heavy metals from wastewater has always been in the public interests and necessities.

One of the most interesting bio-based ion exchange resins is cellulose-based ion exchange resin due to its low cost, non-toxicity, high sorption capacity, biodegradation, and regenerating capability. Cellulose is a natural macromolecular compound and one of the most abundant renewable resources in nature. More importantly, it is a biopolymer, an eco-friendly material for environment. Moreover, cellulose possesses the hydroxyl groups $(-\mathrm{OH})$ at the carbon atom positioned at $2^{\text {nd }}, 3^{\text {rd }}$ and $6^{\text {th }}$ which are possibly active central sites for chemical modification and incorporation of effective chelating functional groups such as $-\mathrm{SO}_{3} \mathrm{H},-\mathrm{NH}_{2} \mathrm{OH}$, and $-\mathrm{COOH}$. These increase the adsorption capacity several times in the removal of heavy metal pollutants from the wastewater.

A variety of cellulosic biomass such as banana stem, sugarcane bagasse, moso bamboo, wood, cotton, reed, straw and other plants fibers has been modified. However, the interesting cellulose that is suitable for synthetic cellulose-based ion exchange resin is water hyacinth (Eichhornia crassipes). The water hyacinth is an aquatic weed that can be found in natural water resources. If they are so abundant in water resources, it will cause troubles and lead to hazard and wastewater.

During this time, chemical modification of cellulose mainly includes cellulose-based composites with organic polymers or hybrid materials, grafting copolymerization $[1,2]$ and the direct chemical functionalization of the hydroxyl groups on the cellulose such as esterification, etherification, and sulfonation [7-9]. The esterification is one of the most popular chemical modifications due to its easy accessibility and not complicated processes. It may choose chemicals that are cheaper and less toxic for production process.

Moreover, the cellulose derivatives were modified via esterification reaction. For example, hydroxyethyl cellulose was functionalized with phthaloyl chloride, isophthaloyl chloride and terephthaloyl choride [10]. However, the only disadvantage of cellulose derivatives is higher cost of the substrates because some cellulose derivatives are relatively expensive.

In addition, the cellulose is functionalized with commercial chelating agents such as D-penicillamine, meso-2,3-dimercaptosuccinic acid (DMSA), EDTA, and deferasirox [11]. There is also cellulose modification via esterification with carboxylic acid anhydride as a modifying agent or chelating agent. They are used in many fields of applications to deal with numerous issues of pollution.

Haier Chen et al. investigated the adsorption of $\mathrm{Pb}$ (II) from aqueous solution by mercerization of moso bamboo with chemically modified pyromellitic dianhydride (CMMB). The results clearly showed that the equilibrium adsorption capacity of CMMB adsorbent was about 2.7 times higher than activated carbon. This indicates that the CMMB adsorbent has good adsorption effect on $\mathrm{Pb}(\mathrm{II})$. After three adsorption-desorption cycles, the adsorption efficiency was decreased by maintaining the efficiency of above $80 \%$ [9]. However, the disadvantage is the fact that CMMB was synthesized from moso bamboo, a kind of winter bamboo and also a rare wood yet commercial one. Undoubtedly, moso bamboo and its derivatives like CMMB are extremely pricey. Simply because moso bamboo is not suitable for planting in tropical climate like Thailand. Moreover, $3,3^{\prime}, 4,4^{\prime}$ - benzophenone tetracarboxylic dianhydride (BPTCD) has been used to modify cellulose structure via esterification for multifunctional finishing or photoactive antibacterial cotton fabrics $[12,13]$. Therefore, PMDA and BPTCD are our main focus of the chelating agents, the modified agents for esterification reaction with cellulose because the structure contains two carboxylic acid anhydride groups that could be efficient chelating functional groups for removing those heavy metal cations. These two compounds are relatively cheap and low toxicity. Thus, these synthetic ion exchange resins are eco-friendly and low cost.

The purpose of this work is to develop the novel cellulose-based ion exchange resins from water hyacinth by modifying with pyromellitic dianhydride (PMDA) and 3,3',4,4' - benzophenone tetracarboxylic dianhydride (BPTCD) as chelating agents. These resins were characterized by FTIR, XRD, SEM, and TGA analysis. Furthermore, the effect of chelating agents i.e., type and ratio on the removal of heavy metal cations such as $\mathrm{Pb}^{2+}$, $\mathrm{Cd}^{2+}, \mathrm{Cu}^{2+}$, and $\mathrm{Ni}^{2+}$ from single-metal aqueous solutions had been investigated in optimum adsorption conditions.

\section{Experimental}

\subsection{Materials}

Cellulose biomass was prepared from the stem of water hyacinth (Eichhornia crassipes, Thailand) by alkaline treatment process. Pyromellitic dianhydride (PMDA), $3,3^{\prime}, 4,4^{\prime}$ - benzophenone tetracarboxylic dianhydride (BPTCD), lead nitrate $\left(\mathrm{Pb}\left(\mathrm{NO}_{3}\right)_{2}\right)$, and nickel acetate tetrahydrate $\left(\mathrm{Ni}\left(\mathrm{CH}_{3} \mathrm{COO}\right)_{2} \cdot 4 \mathrm{H}_{2} \mathrm{O}\right)$ were purchased from Sigma Aldrich, Singapore. Cadmium nitrate tetrahydrate $\left(\mathrm{Cd}\left(\mathrm{NO}_{3}\right)_{2} \cdot 4 \mathrm{H}_{2} \mathrm{O}\right)$ was obtained from KEMAUS, Australia. Copper sulfate pentahydrate $\left(\mathrm{CuSO}_{4} \cdot 5 \mathrm{H}_{2} \mathrm{O}\right)$ was purchased from HIMEDIA, India. Sodium hydroxide $(\mathrm{NaOH})$ was purchased from QREC CHEMICAL, Thailand. Hydrochloric acid ( $\mathrm{HCl}$ ), acetone, ethanol and N,N-dimethylformamide (DMF) were obtained from RCI Labscan, Thailand. All other chemical reagents were analytical grade and they were used directly without further purification.

\subsection{Preparation of cellulose from water hyacinth}

Cellulose biomass was prepared from the stem of water hyacinth (Eichhornia crassipes) by the alkaline treatment process. Firstly, stems of water hyacinth were cut to small pieces and washed with ultrapure water several times then sun-dried outdoor for $48 \mathrm{hr}$. Afterward, the dried water hyacinth was ground until it became powder and was sieved through 140-mesh sieve. The dried powder of $20 \mathrm{~g}$ was soaked in $500 \mathrm{ml}$ of $5 \% \mathrm{w} / \mathrm{v} \mathrm{NaOH}$ solution at room temperature for $24 \mathrm{hr}$ in order to remove hemicellulose, lignin, wax, and other impurities 
from biomass. After alkaline treatment, these powders were filtered and washed with ultrapure water until the $\mathrm{pH}$ was neutral at about 7-8. Finally, cellulose powder from water hyacinth was dried in a hot air oven at $70{ }^{\circ} \mathrm{C}$ for $24 \mathrm{hr}$ [9].

\subsection{Preparation of cellulose-based ion exchange resins}

Cellulose-based ion exchange resins were prepared via esterification reaction between cellulose from water hyacinth with two different chelating agents (PMDA and BPTCD), as shown in Fig.1. Firstly, $5 \mathrm{~g}$ of cellulose and each chelating agent (1:1 and 1:3 mole fraction of repeating unit of cellulose per chelating agents) were dispersed in $250 \mathrm{ml} \mathrm{DMF}$. Then, the reaction mixture was stirred at $70{ }^{\circ} \mathrm{C}$ for $20 \mathrm{hr}$. After esterification reaction, the materials were washed with DMF, ultrapure water, $0.1 \mathrm{M} \mathrm{NaOH}$, ethanol and acetone, respectively. These cellulose-based ion exchange resins (Cell-PMDA and Cell-BPTCD) were dried in a hot air oven at $60{ }^{\circ} \mathrm{C}$ for $24 \mathrm{hr}$. Finally, the dried resins were kept in desiccator and the percentage graft yield $\left(P_{g}\right)$ was calculated by the following equation (1).

$$
P_{\mathrm{g}}=\left[\left(w_{1}-w_{2}\right) / w_{1}\right] \times 100
$$

Where $w_{l}$ is the weight of cellulose-based ion exchange resins (g) and $w_{2}$ is the weight of cellulose from water hyacinth $(\mathrm{g})$.

\subsection{Characterizations}

\subsubsection{FTIR analysis}

The chemical structure and functional groups of raw biomasses, cellulose from water hyacinth, and cellulosebased ion exchange resins were characterized with fourier transform infrared spectrometer; FTIR (VERTEX70, Bruker, USA). The FTIR spectra were recorded in the range of $4000-400 \mathrm{~cm}^{-1}$ and used a resolution of $4 \mathrm{~cm}^{-1}$.

a)<smiles>CCOC(=O)c1cc(C(=O)O)c(C(=O)OCC(C)C)c(C(=O)OCC(C)C)c1</smiles>

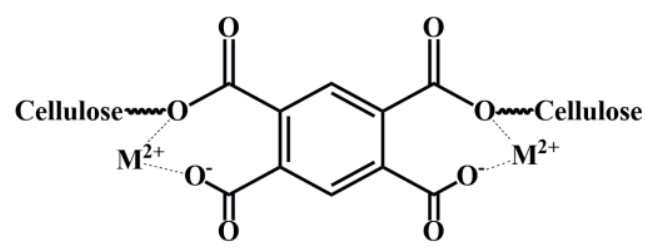

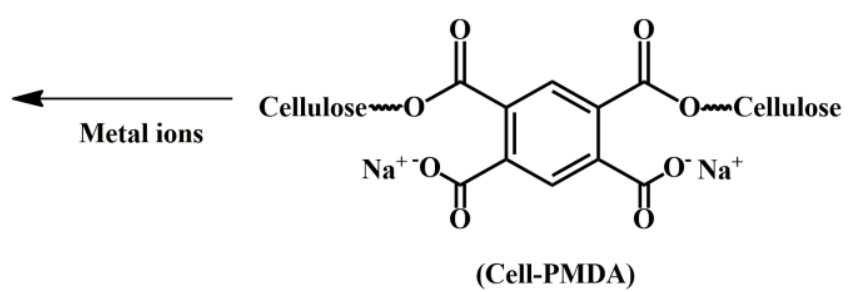

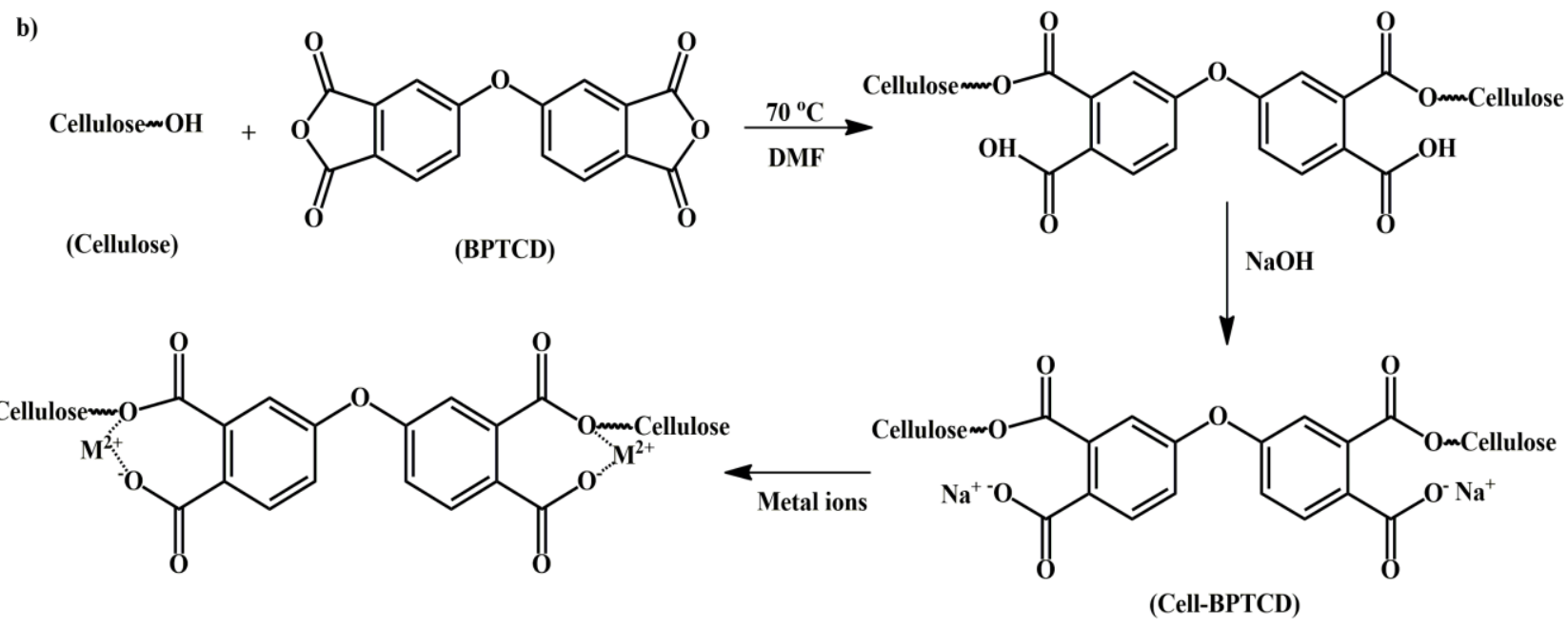

Fig. 1. Synthesis scheme and the adsorption mechanism of heavy metal cations on cellulose-based ion exchange resins for a) Cell-PMDA, and b) Cell-BPTCD resin. 


\subsubsection{XRD}

The crystallinity index of samples was measured with Xray diffractometer; XRD (MAXima_X XRD7000, Shimadzu, Japan). $\mathrm{Cu} \mathrm{K} \alpha$ radiation was generated at 30 $\mathrm{kV}$ and $20 \mathrm{~mA}$. XRD patterns were obtained with continuous scan mode at a scan speed of 5 degrees $/ \mathrm{min}$ from $10^{\circ}$ to $80^{\circ}$. The crystallinity index $(\mathrm{Cr} I)$ was obtained by crystalline and amorphous intensity values obtained from the diffraction pattern. The $C r I$ was calculated by the following equation (2) $[1,9,14,15]$.

$$
\% C r I=\left[\left(I_{002}-I_{18}\right)^{\prime} / I_{002}\right] \times 100
$$

Where $I_{002}$ is the maximum intensity at the (002) lattice diffraction at $2 \theta$ between $22^{\circ}$ and $23^{\circ}$ in the crystalline region. $I_{18}{ }^{\circ}$ is the intensity of the background scatter at $2 \theta=18^{\circ}$.

\subsubsection{SEM}

The surface morphology and structure of samples were observed by using scanning electron microscope; SEM (TM3030, Hitachi, Japan) with an accelerating voltage of $15 \mathrm{kV}$. The cellulose powder before and after modification with esterification reaction were put on an aluminium stub and coated with a thin gold layer through sputtering process.

\subsubsection{TGA}

The thermal stability of cellulose and cellulose-based ion exchange resins from water hyacinth were investigated by thermogravimetric analyzer; TGA (Perkin Elmer TGA7, USA). The powdered samples about 3-7 mg were heated from $50{ }^{\circ} \mathrm{C}$ to $700{ }^{\circ} \mathrm{C}$ at a heating rate of 10 ${ }^{\circ} \mathrm{C} /$ min under $\mathrm{N}_{2}$ atmosphere.

\subsection{Adsorption experiments}

The stock solution of $100 \mathrm{mg} / \mathrm{L}$ of $\mathrm{Cu}(\mathrm{II}), \mathrm{Pb}(\mathrm{II}), \mathrm{Cd}(\mathrm{II})$, and $\mathrm{Ni}$ (II) metal cations were prepared in distilled water by taking a definite amount of $\mathrm{CuSO}_{4} \cdot 5 \mathrm{H}_{2} \mathrm{O}, \mathrm{Pb}\left(\mathrm{NO}_{3}\right)_{2}$, $\mathrm{Cd}\left(\mathrm{NO}_{3}\right)_{2} \cdot 4 \mathrm{H}_{2} \mathrm{O}$, and $\mathrm{Ni}\left(\mathrm{CH}_{3} \mathrm{COO}\right)_{2} \cdot 4 \mathrm{H}_{2} \mathrm{O}$. Cellulosebased ion exchange resins were used as an adsorbent for the removal of each heavy metal cation from a singlemetal aqueous solution.

Each heavy metal cation adsorption was studied under the optimal conditions by using initial metal concentration of $100 \mathrm{mg} / \mathrm{L}$, solution $\mathrm{pH} \approx 5$, room temperature, stirring at $400 \mathrm{rpm}$ and contact time of 180 min. Firstly, $50 \mathrm{mg}$ of dried cellulose-based ion exchange resin was added to a $100 \mathrm{ml}$ erlenmeyer flask containing $50 \mathrm{ml}$ of a heavy metal aqueous solution. Then, the erlenmeyer flask was sealed and stirred at the room temperature. After adsorption, the residual concentration of heavy metal cation in the solution was measured by inductively coupled plasma spectrometer (ICP).
The adsorption experiment was repeated three times and the results have been given in terms of average values. The adsorption capacity of cellulose-based ion exchange resins at equilibrium $\left(q_{e}, \mathrm{mg} / \mathrm{g}\right)$ was determined by the following equation (3).

$$
q_{\mathrm{e}}=\left[\left(C_{0}-C_{e}\right) \times V\right] / W
$$

Where $C_{0}$ and $C_{e}$ is the initial and equilibrium concentration of adsorbate in heavy metal aqueous solutions $(\mathrm{mg} / \mathrm{L}), V$ is the volume of solution (L) and $W$ is the weight of the dried cellulose-based ion exchange resins $(\mathrm{g})$.

\section{Results and Discussion}

\subsection{Synthesis of cellulose-based ion exchange resins from water hyacinth}

Before modification, the water hyacinth powder was immersed in $5 \% \mathrm{w} / \mathrm{v}$ of $\mathrm{NaOH}$ to remove hemicellulose and lignin from biomass. Moreover, the alkaline treatment process also increased the specific surface area of fiber. As a consequently, hydroxyl groups of cellulose would be easily accessible $[9,16]$. The hydroxyl groups $(-\mathrm{OH})$ positioned at $2^{\text {nd }}, 3^{\text {rd }}$, and $6^{\text {th }}$ carbon atoms of cellulose ring structure were susceptible to be the active sites for chemical reaction [1]. PMDA and BPTCD were used as chelating agent to react with the hydroxyl groups of cellulose from water hyacinth at $70{ }^{\circ} \mathrm{C}$ for $20 \mathrm{hr}$ in DMF. This reaction was the esterification between anhydride groups of chelating agents with hydroxyl groups of cellulose by obtaining the ester groups, crosslinking, and grafting on the cellulose materials. Then, cellulose-based ion exchange resins would be washed with saturated solution of $\mathrm{NaOH}$ to change the carboxylic group into carboxylate and enable them to increase their chelating ability as shown in Fig. 1.

Percentage graft yield $\left(P_{g}\right)$ of cellulose-based ion exchange resins were compared in Table 1 . These results showed that the percentage graft yield was increased dramatically with the raise of chelating ratio from 1 to 3 moles with the sacrifice of the cost because of the need for more chelating agents amount used.

Table 1. Percentage graft yield $\left(P_{g}\right)$ of cellulose-based ion exchange resins.

\begin{tabular}{|c|c|c|c|c|}
\hline \multirow{2}{*}{ Resins } & \multirow{2}{*}{$\begin{array}{c}\text { Cellulose } \\
\text { (mole) }\end{array}$} & \multicolumn{2}{|c|}{$\begin{array}{c}\text { Chelating agent } \\
\text { (mole) }\end{array}$} & \multirow{2}{*}{$\begin{array}{c}\boldsymbol{P}_{\boldsymbol{g}} \\
\mathbf{\%})\end{array}$} \\
\cline { 3 - 4 } & & PMDA & BPTCD & \\
\hline Cell -PMDA11 & 1 & 1 & - & 19.18 \\
\hline Cell -PMDA13 & 1 & 3 & - & 30.66 \\
\hline Cell -BPTCD11 & 1 & - & 1 & 20.96 \\
\hline Cell -BPTCD13 & 1 & - & 3 & 32.25 \\
\hline
\end{tabular}

The presence of ester group and cross-linking including grafted chains on the cellulose from water hyacinth has been confirmed by the FTIR, XRD, SEM, and TGA techniques. 


\subsection{FTIR analysis}

Different functional groups of untreated water hyacinth (WHC) were identified with FTIR as shown in Fig. 2(a). The FTIR spectra of WHC showed the typical characteristic peaks of lignocellulose that included cellulose, hemicellulose, and lignin. The broad band at $3401.42 \mathrm{~cm}^{-1}$ would be $\mathrm{O}-\mathrm{H}$ stretching in hydroxyl group of biomasses. The peak at $2922.76 \mathrm{~cm}^{-1}$ corresponded to $\mathrm{C}-\mathrm{H}$ stretching of the alkane. The peak at $1733.14 \mathrm{~cm}^{-1}$ was attributed to $\mathrm{C}=\mathrm{O}$ stretching due to either acetyl or uronic ether linkages of carboxylic group in the ferulic and p-coumeric acids, two major phenolic acids in lignin biopolymer. The peak at $1637 \mathrm{~cm}^{-1}$ was associated with $\mathrm{O}-\mathrm{H}$ bending due to water or humidity adsorption in the biomass sample. Additionally, the peak at $1428.35 \mathrm{~cm}^{-1}$ represented the $-\mathrm{CH}_{3}$ asymmetric bending. The characteristic band at $1373.59 \mathrm{~cm}^{-1}$ corresponded to the $\mathrm{C}=\mathrm{C}$ linkages which was presented in the guaiacyl ring of the lignin. The peaks at $1324.82 \mathrm{~cm}^{-1}$ normally indicated $-\mathrm{CH}_{2}$ wagging which was typically presented in the hemicellulose and cellulose. The peak at 1249.93 $\mathrm{cm}^{-1}$ represented the C-O-C asymmetric stretching of aryl-alkyl ether in the lignin structure. The peak at $1050.93 \mathrm{~cm}^{-1}$ exhibited the $\mathrm{C}-\mathrm{O}$ stretching of secondary alcohols and ethers functional group in hemicellulose and cellulose. Furthermore, the peak at $897 \mathrm{~cm}^{-1}$ explained the C-O-C symmetric stretching of the $\beta-(1$, 4)-glycosidic linkage in cellulose and xylose unit in hemicellulose [1, 14, 15, 17-20].

Fig. 2(b) showed the FTIR spectrum of cellulose from water hyacinth after alkaline treatment process. This FTIR spectrum was similar to untreated WHC. Only some major peaks were changed and shifted in the terms of shape, location, and transmittance of the FTIR spectral bands. The disappearance of $\mathrm{C}=\mathrm{O}$ stretching at $1733.14 \mathrm{~cm}^{-1}$ peak from the alkali pretreated WHC sample indicated that lignin was removed from water hyacinth and obtained the effective delignification. Moreover, the reduction of peak intensity for $\mathrm{O}-\mathrm{H}$ bending, $\mathrm{C}=\mathrm{C}$ stretching, $\mathrm{C}-\mathrm{O}-\mathrm{C}$ asymmetric stretching, and $\mathrm{C}-\mathrm{O}$ stretching exhibited at 1625.28, 1370.64, 1245.46 , and $1060.50 \mathrm{~cm}^{-1}$, respectively. It related to decreasing $\mathrm{C}=\mathrm{C}$ bond of guaiacyl ring, $\mathrm{C}-\mathrm{O}-\mathrm{C}$ bond of aryl-alkyl ether in lignin and $\mathrm{C}-\mathrm{O}$ bond of xylan in hemicellulose due to the dissolution of hemicellulose and lignin in $\mathrm{NaOH}$ solution. Therefore, the remaining was mostly cellulose $[14,18]$. Furthermore, the FTIR spectrum obtained was somewhat similar to commercial cellulose $[2,17,20]$.

Fig. 2(c-f) illustrated the FTIR spectrum of cellulosebased ion exchange resins that were synthesized via esterification by using different types and ratio of chelating agents (PMDA and BPTCD). After modification of cellulose from water hyacinth, the FTIR spectra of Cell-PMDA11, Cell-PMDA13, CellBPTCD11, and Cell-BPTCD13 resins showed additional peaks of $\mathrm{C}=\mathrm{C}$ stretching (aromatic) about $1500 \mathrm{~cm}^{-1}$ and $\mathrm{C}=\mathrm{O}$ stretching of ester group at 1727.92, 1727.79, 1726.91, and $1727.52 \mathrm{~cm}^{-1}$, respectively [9, 21-23]. The ratio of chelating agent was increased from 1 to 3 moles that affected on the increment of $\mathrm{C}=\mathrm{O}$ stretching.
Moreover, the bands of $\mathrm{O}-\mathrm{H}$ stretching and $\mathrm{O}-\mathrm{H}$ bending at 3404 and $1625 \mathrm{~cm}^{-1}$ showed relatively broader peak with lesser intensity. These results confirmed the esterification reaction between anhydride groups of chelating agents with hydroxyl groups of cellulose due to the apparent peak of the ester group [22]. Furthermore, the ester and carboxylate bands in FTIR spectra indicated that the PMDA and BPTCD was introduced into cellulose via the formation of the ester bond with the consequent release of a carboxyl group [9].

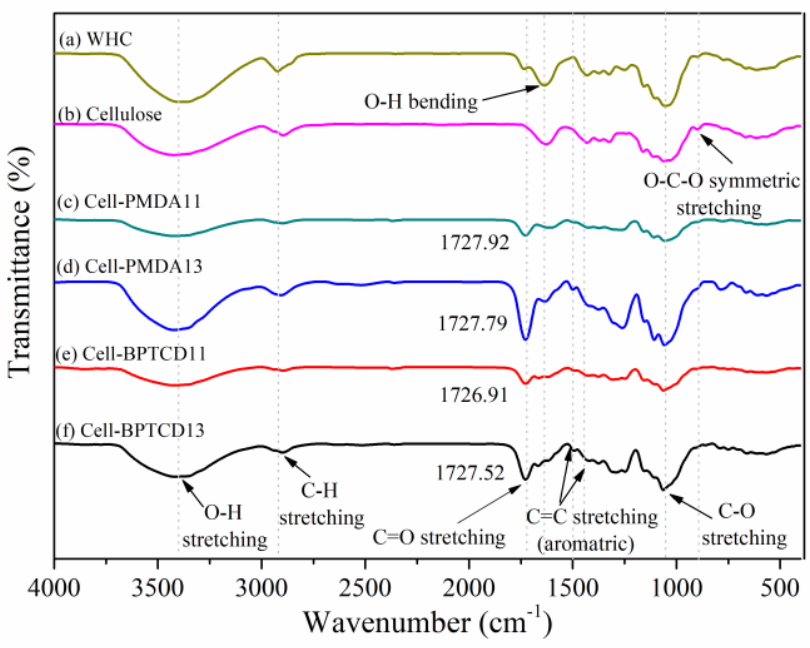

Fig. 2. FTIR spectra of (a) Water hyacinth (WHC), (b) Cellulose from water hyacinth, (c) Cell-PMDA11, (d) Cell-PMDA13, (e) Cell-BPTCD11, and (f) Cell-BPTCD13.

\subsection{X-ray diffraction analysis}

$\mathrm{X}$-ray diffraction patterns of untreated and treated water hyacinth and cellulose-based ion exchange resins were shown in Fig. 3. The crystallinity indexes $(\mathrm{Cr})$ were represented in Table 2. The XRD pattern of WHC in Fig. 3(a) exhibited the diffraction peaks at $15.20^{\circ}, 21.84^{\circ}$, $28.54^{\circ}$, and $40.76^{\circ}$, while the diffraction peaks of alkali pre-treated WHC in Fig. 3(b) appeared at $15.04^{\circ}$ and $22.34^{\circ}$ which corresponded with (101) and (002) crystal planes of cellulose, respectively [2]. However, the disappearance of two diffraction peaks at $28.54^{\circ}$ and $40.76^{\circ}$ had proved that the alkali-treatment process could improve the rearrangement of cellulose chain. Moreover, the crystallinity indexes $(\mathrm{Cr} I)$ of untreated and alkalitreated WHC were $55.17 \%$ and $64.47 \%$, respectively. The results indicated that the alkaline treatment could increase the crystallinity index of cellulose by removing the amorphous hemicellulose and lignin from biomass. Furthermore, alkali treatment would more likely expose hydroxyl group of the water hyacinth-cellulose on surface. This led to more attachments of functional group and subsequently the higher selectivity for metal ion adsorption. Previous studies had shown results similarly and reported $[9,14,15]$.

Fig. 3(c-f) showed the XRD patterns of cellulosebased ion exchange resins. These resins had shown similar diffraction patterns and characteristic peak at $2 \theta$ about $16^{\circ}$ and $22^{\circ}$. These two diffraction peaks shifted and the intensity decreased when compared with 
cellulose from water hyacinth. This result indicated that the substrate had been changed after esterification and chemical modification [9]. Moreover, the crystallinity index $(\mathrm{Cr} I)$ of Cell-PMDA11, Cell-PMDA13, CellBPTCD11, and Cell-BPTCD13 were 56.41\%, 51.47\%, $49.38 \%$, and $48.65 \%$, respectively. These results showed that the crystallinity index decreased and the amorphous region increased with esterification and higher chelating agent ratio. Because it raised the amount of grafting and crosslinking that broke the crystallinity formation of cellulose [1, 2, 9]. Furthermore, Cell-BPTCD possesses the crystallinity index less than Cell-PMDA because BPTCD structure is relatively larger and more steric effect than PMDA structure, which inhibited the crystalline packing of cellulose. These results confirmed that cellulose from water hyacinth was grafted and crosslinked with PMDA or BPTCD, which were associated with the percentage graft yield and FTIR result described earlier.

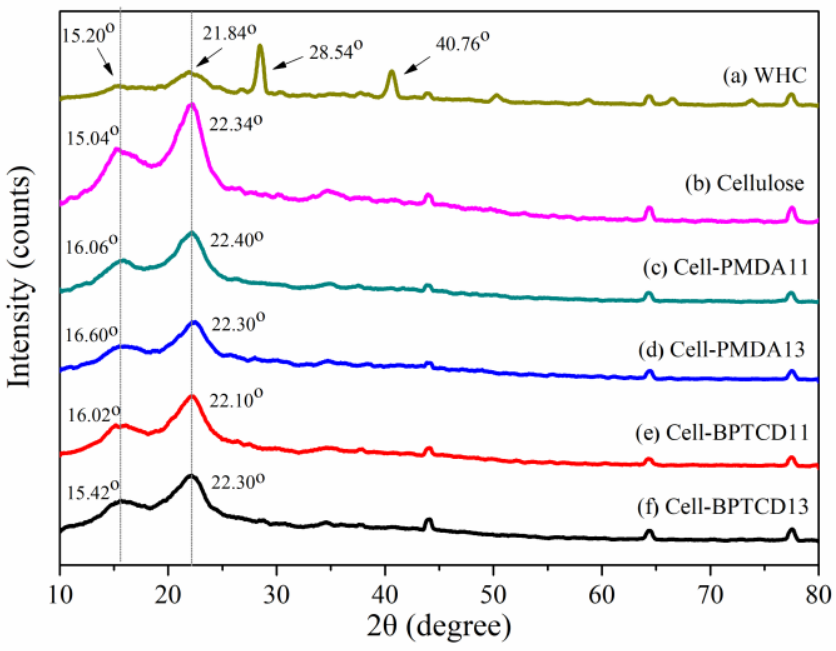

Fig. 3. XRD pattern of (a) Water hyacinth (WHC), (b) Cellulose from water hyacinth, (c) Cell-PMDA11, (d) Cell-PMDA13, (e) Cell-BPTCD11, and (f) Cell-BPTCD13.

Table 2. The Crystallinity index $(\mathrm{Cr} I)$ of untreated and treated water hyacinth and cellulose-based ion exchange resins.

\begin{tabular}{|l|c|}
\hline \multicolumn{1}{|c|}{ Resins } & CrI (\%) \\
\hline Water hyacinth (WHC) & 55.17 \\
\hline Cellulose from water hyacinth & 64.47 \\
\hline Cell -PMDA11 & 56.41 \\
\hline Cell -PMDA13 & 51.47 \\
\hline Cell -BPTCD11 & 49.38 \\
\hline Cell -BPTCD13 & 48.65 \\
\hline
\end{tabular}

\subsection{Surface morphology analysis}

The surface morphology of untreated water hyacinth (WHC) was shown in Fig. 4(a). The untreated WHC showed a firm, smooth surface and there were plenty of minute impurities on the surface. On the other hand, alkali pretreated WHC sample exhibited highly ordered structure, clearly surface, and rougher than untreated WHC because some hemicellulose and lignin dissolved in $5 \% \mathrm{w} / \mathrm{v}$ of $\mathrm{NaOH}$ solution until most of the structure remains were cellulose from water hyacinths, as shown in Fig. 4(b). Moreover, there were spaces between fibers that might facilitate the chances of a chemical reaction between hydroxyl functional groups on cellulose with the chelating agent. As a result, there were multiple active sites of functional groups, which could chelate with metal ions immensely $[1,9,14,18]$.
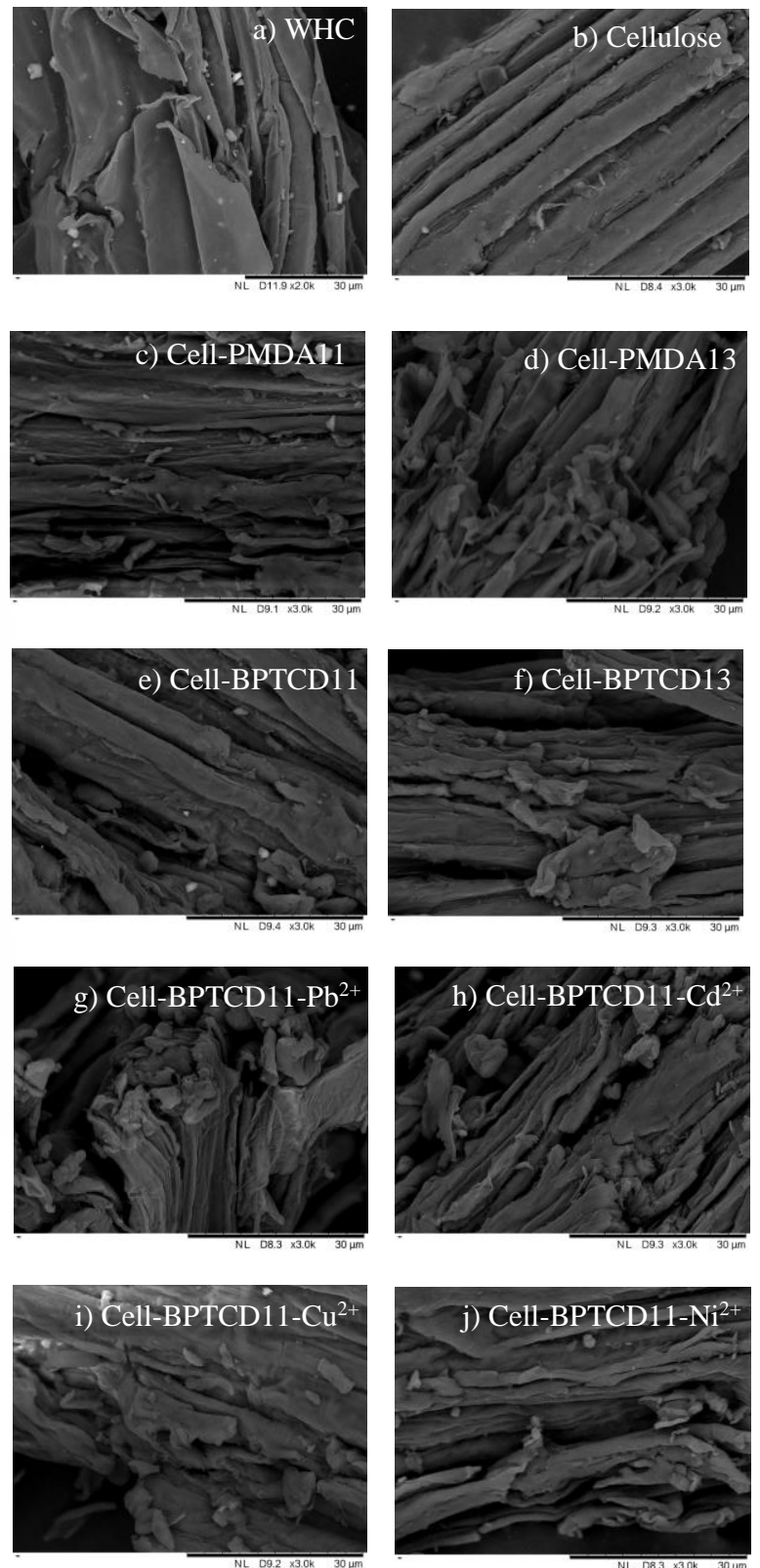

Fig. 4. Surface morphology of a) Water hyacinth (WHC), b) Cellulose from water hyacinth, c) Cell-PMDA11, d) Cell-PMDA13, e) Cell-BPTCD11, f) Cell-BPTCD13, and (g-j) After adsorption of $\mathrm{Pb}^{2+}, \mathrm{Cd}^{2+}, \mathrm{Cu}^{2+}, \mathrm{Ni}^{2+}$, respectively.

Fig. 4(c-f) showed surfaces of cellulose-based ion exchange resin such as Cell-PMDA11, Cell-PMDA13, Cell-BPTCD11, and Cell-BPTCD13, respectively. The results shown were cluster structure, irregular and rougher surface than cellulose from water hyacinth. The rough surface was increased with the increase of chelating agent ratio. These results confirmed grafting or crosslinking on cellulose surface, which correlated with the FTIR analysis. The surface morphologies of 
cellulose-based ion exchange resin with heavy metal ions adsorption were represented in Fig. 4(g-j). It was clear from the SEM images that surfaces of cellulosebased ion exchange resin became rougher and more agglomerated due to adsorption or ion exchange mechanism of heavy metal cations $[1,2]$. Therefore, it could be confirmed that cellulose-based ion exchange resins adsorbing heavy metal cations in the contaminated wastewater effectively.

\subsection{Thermogravimetric analysis}

The TGA curves of untreated water hyacinth (WHC) were shown in Fig. 5(a), which illustrated the thermal degradation of untreated WHC in four stages. The first stage of weight loss occurred below $100{ }^{\circ} \mathrm{C}$ because of water elimination and volatile evaporation from the sample. The second stage of weight loss between the range of $130-220{ }^{\circ} \mathrm{C}$ was attributed to hemicellulose decomposition, followed by thermal degradation of cellulose at temperature range of $220-385{ }^{\circ} \mathrm{C}$ in the third stage. Finally, it was the lignin decomposition at the range of $415-525{ }^{\circ} \mathrm{C}$ since lignin was more stable and only decomposed at higher temperatures $[1,24]$.

On the other hand, The TGA curve of alkali-treated WHC in Fig. 5(b) represented being after alkaline treatment with only the two stage of thermal degradation. The first stage at lower than $100{ }^{\circ} \mathrm{C}$ which caused by water evaporation and the latter stage of decomposition was cellulose decomposition at temperature range of $230-390{ }^{\circ} \mathrm{C}$ [2]. These results indicated that the alkali-treated WHC had higher thermal stability when compared with untreated WHC due to the disposal of amorphous hemicellulose and lignin via dissolution in $\mathrm{NaOH}$ solution. Moreover, this result confirmed that the major remaining after alkaline treatment was cellulose from water hyacinth and it was consistent with the FTIR, XRD and SEM results.

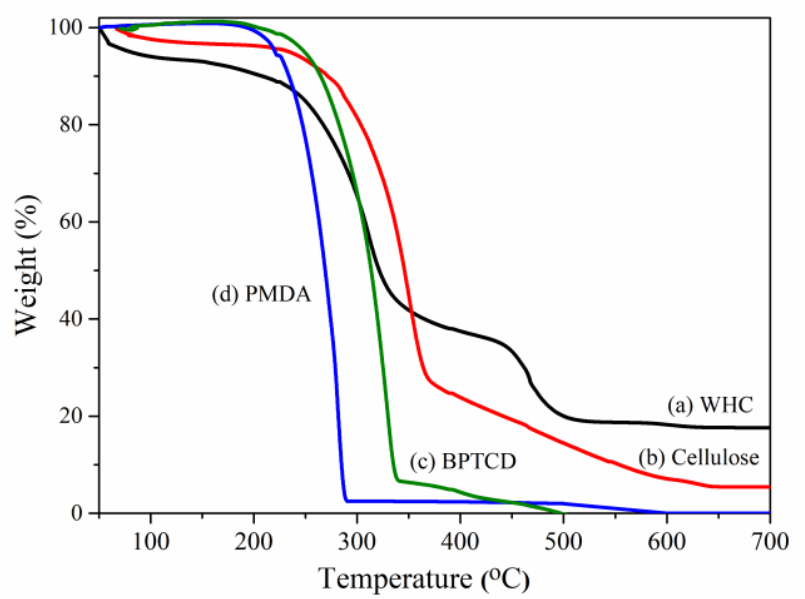

Fig. 5. TGA curve of raw materials (a) untreated WHC, (b) Cellulose, (c) BPTCD, and (d) PMDA.

Fig. 5(c-d) displayed the TGA curves of BPTCD and PMDA as chelating agent. The result showed that BPTCD and PMDA had lower thermal stability than WHC-cellulose and they showed only one stage of thermal decomposition. The thermal degradation of BPTCD occurred at temperature range of $187-344{ }^{\circ} \mathrm{C}$ [25], while PMDA had the thermal degradation at 180 $290{ }^{\circ} \mathrm{C}[23,26]$.

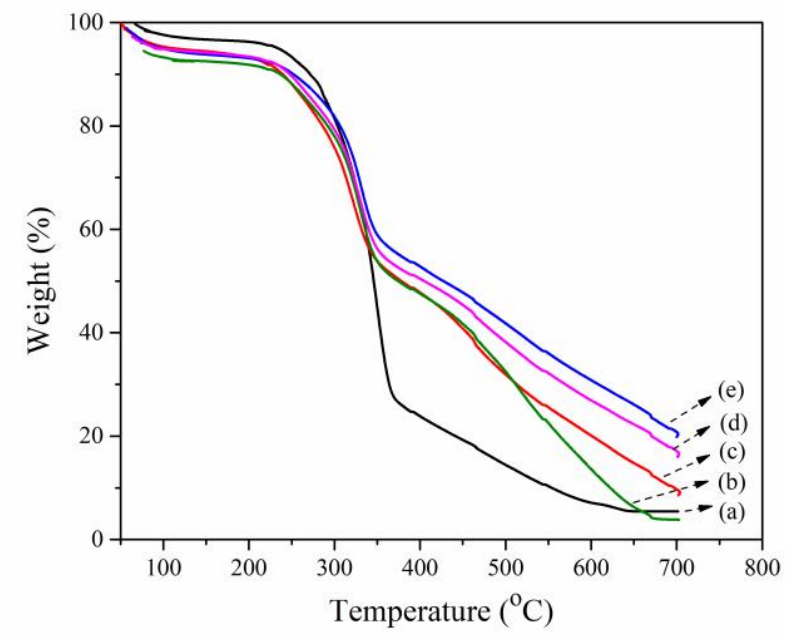

Fig. 6. TGA curve of (a) WHC-cellulose, (b) Cell-BPTCD11, (c) Cell-PMDA11, (d) Cell-BPTCD13, and (e) Cell-PMDA13

TGA analysis was employed to compare thermal stability of WHC-cellulose and cellulose-based ion exchange resins as shown in Fig. 6. The WHC-cellulose illustrated the highest decomposition onset temperature and small amount of degraded residues as shown in Fig. 6(a), while TGA curves of the cellulose-based ion exchange resin showed that all resins had similar thermal degradation behavior with three stages of weight loss, which it contradicted to WHC-cellulose. The first stage was due to the loss of water and volatile contents in the resins, followed by the degradation of ester crosslinks and the third stage was mainly contributed to the degradation of the cellulose chains as shown in Fig. 6(bd). The main decomposition stage of resins was evidently extended and the rate was reduced. In addition, residual increased as compared with WHC-cellulose. These TGA results exhibited that the cellulose-based ion exchange resins had lower thermal stability than WHC-cellulose since the formation of unstable ester linkage formed during crosslinking or esterification reaction, as previously noted in the literature for the related ester products $[12,13,23]$. Moreover, the thermal degradation residue of the cellulose-based ion exchange resins was increased with the increment of PMDA or BPTCD ratio. Whereas the decomposition temperature decreased slightly due to the raising of carbon-carbon network, thermo-oxidative stability, and heat resistant properties of the crosslinker. In addition, the PMDA and BPTCD acted as chelating agents, grafting and crosslinking groups on the cellulose that increased carbonization rate of the cellulose during thermal degradation and led to high degradation residues [2, 12]. Despite the thermal stability of cellulose-based ion exchange resins decreased when compared to WHC-cellulose. However, it was clear that these resins were heat stable, having good thermal stability, not being affected at the applicable temperatures. 


\subsection{Adsorption capacity of heavy metal cations on cellulose based ion exchange resins}

The adsorption capacity of heavy metal cations on cellulose-based ion exchange resins as shown in Fig.7 indicated the influences of type and ratio of chelating agents affected on metal ion adsorption in single-metal aqueous solution. Nevertheless, these resins illustrated the high adsorption capacities of more than $98 \mathrm{mg} / \mathrm{g}$ for heavy metal cation. While the Cell-BPTCD11 resin showed the highest adsorption capacity for $\mathrm{Pb}^{2+}, \mathrm{Ni}^{2+}$ and $\mathrm{Cd}^{2+}, \mathrm{Cu}^{2+}$ of $99.91,99.88,99.83$, and $99.79 \mathrm{mg} / \mathrm{g}$, respectively.

However, the Cell-BPTCD possessed slightly higher adsorption capacity than the Cell-PMDA because the BPTCD chelating agent on the cellulose had equivalent carboxylic acid group with the PMDA, which could form the chelate compounds, ion exchange, or electrostatic interaction with a heavy metal cation. Another reason is the BPTCD structure has relatively larger and more steric effect than the PMDA structure. This led to larger porous and more free volume inside the resin. Thus, heavy metal cations had higher diffusion rate and ion mobility [10]. It meant that heavy metal cations could easily diffuse into the structure of resin. As a result, this adsorption took place faster and more efficient. These results indicated that the adsorption process was controlled by the ion exchange mechanism as shown in Fig. 1.

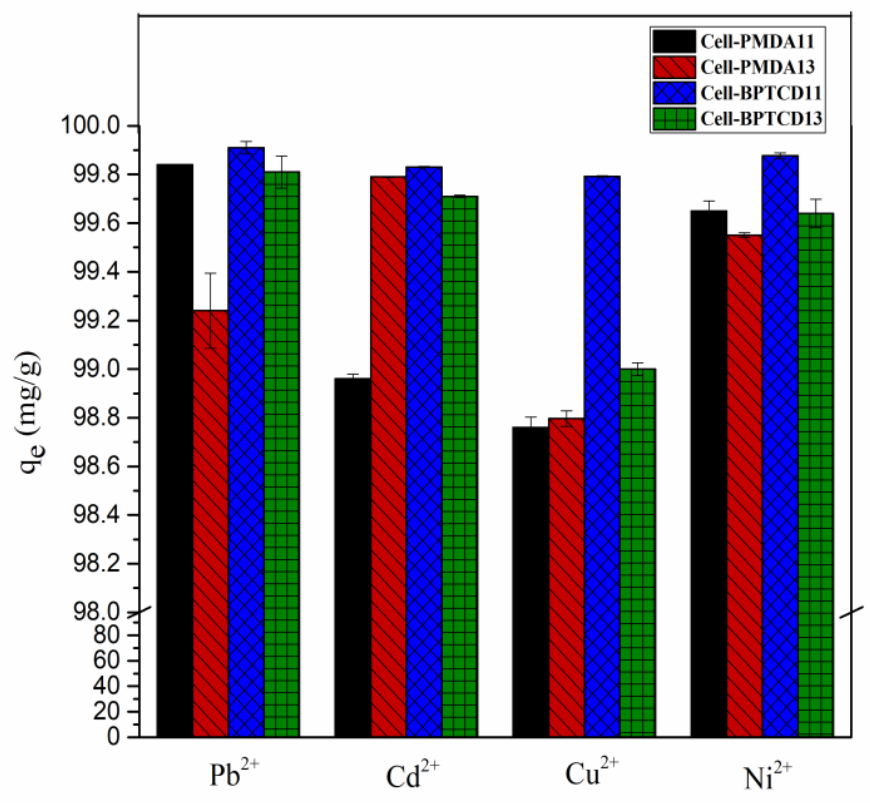

Fig. 7. Adsorption capacity of heavy metal cation on CellPMDA11, Cell-PMDA13, Cell-BPTCD11, and Cell-BPTCD13 resins. (Initial concentration $100 \mathrm{mg} / \mathrm{L}$; contact time $180 \mathrm{~min}$; stirring rate $400 \mathrm{rpm}$; room temperature; $\mathrm{pH} 5$; resin $50 \mathrm{mg}$ )

Moreover, the adsorption capacity of heavy metal cation on Cell-BPTCD resin decreased with the amplification of BPTCD ratio from 1 to 3 moles. The reason was the number of grafting or ester crosslinking was so excessive with the increase of BPTCD ratio. This led to the decrease of swelling ability that including matrixes of resins becoming narrow and tight. Therefore, it could intercept the movement and then heavy metal cation in aqueous solution could not diffuse into the resin. As a result, the adsorption capacity was declined $[10,27]$.

The adsorption capacity of $\mathrm{Pb}^{2+}$ and $\mathrm{Ni}^{2+}$ on CellPMDA resin decreased with the increment of PMDA ratio due to excessive grafting and crosslinking. While the adsorption capacity of $\mathrm{Cd}^{2+}$ and $\mathrm{Cu}^{2+}$ on Cell-PMDA resin increased with the rise of PMDA ratio due to the augmentation of chelating functional group. Also, it was found that each metal ion adsorption capacity on these resins was unequal which depended on the size and charge density of each metal ion [4].

The Cell-BPTCD11 resin was the focus of this study because it illustrated the highest adsorption capacity of heavy metal cation. The adsorption capacity for each cation increased in the following sequences: $\mathrm{Pb}^{2+}>\mathrm{Ni}^{2+}$ $>\mathrm{Cd}^{2+}>\mathrm{Cu}^{2+}$. Among those ions with the same charge, the tendency of adsorption capacity increased with the radius reduction of heavy metal cations in water (hydrated radius) in the order: $\mathrm{Pb}^{2+}<\mathrm{Ni}^{2+}<\mathrm{Cu}^{2+}<\mathrm{Cd}^{2+}$ as shown in Table 3. Due to electrostatic effect and the metal binding strength increases with the decrement of the hydrated metal cation radius [4, 27, 28]. However, the actual ion exchange of $-\mathrm{COO}^{-} \mathrm{Na}^{+}$group with metal cations also depend on the other factor such as $\mathrm{pH}$, charge density and ionic strength that had influenced on adoption capacity. Moreover, $\mathrm{Pb}^{2+}$ in the aqueous solution possessed the smallest hydrated radius when compared with other cations as seen in Table 3 . It meant that $\mathrm{Pb}^{2+}$ ions could easily diffuse into the resin and could chelate with chelating functional group in the resin with superiority [27].

Table 3. Ionic radius [29, 30], charge density [29], hydratedradius [30] and the adsorption capacity of heavy metal cations on Cell-BPTCD11 resin.

\begin{tabular}{|c|c|c|c|c|}
\hline $\begin{array}{c}\text { Metal } \\
\text { cations }\end{array}$ & $\begin{array}{c}\text { Ionic radius } \\
\mathbf{( A}^{\circ} \mathbf{)}\end{array}$ & $\begin{array}{c}\text { Charge } \\
\text { density }\end{array}$ & $\begin{array}{c}\text { Hydrated } \\
\text { radius }\left(\mathbf{A}^{\circ}\right)\end{array}$ & $\begin{array}{c}\boldsymbol{q}_{\boldsymbol{e}} \\
(\mathbf{m g} / \mathbf{g})\end{array}$ \\
\hline $\mathrm{Pb}^{2+}$ & 1.32 & 0.21 & 4.01 & 99.91 \\
\hline $\mathrm{Ni}^{2+}$ & 0.70 & 1.45 & 4.04 & 99.88 \\
\hline $\mathrm{Cd}^{2+}$ & 0.97 & 0.52 & 4.26 & 99.83 \\
\hline $\mathrm{Cu}^{2+}$ & 0.72 & 1.28 & 4.19 & 99.79 \\
\hline
\end{tabular}

Furthermore, the costs of chelating agents for esterification reaction with cellulose from water hyacinth were compared with commercial cation exchange resin. PMDA and BPTCD are undoubtedly cheaper than many commercial cation exchange resins i.e., Dowex50WX8, Amberchrom 50WX8 and Chelex100 resins. PMDA and BPTCD are cheaper than Dowex50WX8 about 3.3 times and 5 times, respectively [31]. On the other hand, the PMDA and BPTCD are still considered pricey when compared to some commercial resins such as AmberliteIR120, DiaionCR11 and Purolite C160 resins. For example, the cost of PMDA and BPTCD are more expensive than AmberliteIR120 about 3.8 times and 2.8 times, respectively [31]. However, the relatively high cost is feasible because these cellulose-based ion exchange resins are biodegradable and high adsorption capacity while most of these commercial resins are not eco-friendly because of the non-biodegradable matrix of 
the resins. The structural polymeric backbone of these commercial resins is styrene cross-linked with divinylbenzene functionalized with sulfonic acid $[4,5$, 31]. Moreover, the removal of heavy metals from aqueous solution by using Cell-PMDA and Cell-BPTCD resins was found to be cheaper than using the membrane separation method such as Empore ${ }^{\mathrm{TM}}$ SPE Disks about 5.7 times and 7.7 times, respectively [31]. Therefore, the results clearly showed that these cellulose-based ion exchange resins are also eco-friendly and relatively low cost.

The reuse of the adsorbents is very important for keeping the adsorption cost-effective process. There is also the possibility to reuse these cellulose-based ion exchange resins. It is consistent with other researches that investigated other cellulose-based ion exchange resins $[2,9,10]$. After three adsorption-desorption cycles, the adsorption efficiency of chemically modified moso bamboo (CMMB) was decreased to approximately $80 \%$ and above [9]. While after five cycles, the acrylamide/acrylic acid cellulose hydrogel still retained the relatively high adsorption capacity, which indicated the good reusability of the modified cellulose hydrogels [2]. The desorption and reusability of cellulose-based ion exchange resins from water hyacinth would be further studied.

\section{Conclusions}

These novel cellulose-based ion exchange resins from water hyacinth were successfully prepared via esterification with either PMDA or BPTCD. The ester crosslinking or grafting increased with the rise of chelating agent ratio from 1 to 3 moles which correlated to the percentage graft yield results. The FTIR, XRD, SEM, and TGA analysis confirmed that cellulose was functionalized with PMDA or BPTCD. The peak of the ester group had appeared on FTIR spectra of cellulosebased ion exchange resins. SEM images indicated the newly synthetic resins were cluster structure, irregular and rougher surface. Moreover, XRD results showed the decrease of crystallinity index after cellulose modification because the ester crosslinking and grafting broke the crystallinity of the cellulose. The thermal stability of cellulose-based ion exchange resins decreased, but they were still good thermal stability. Furthermore, the Cell-BPTCD possessed higher adsorption capacity than the Cell-PMDA. If the chelating ratio was to be increased, it could possibly decrease the adsorption capacity. However, these resins displayed high adsorption capacities of more than $98 \mathrm{mg} / \mathrm{g}$ for heavy metal cation, at which the Cell-BPTCD11 resin showed the highest adsorption capacity for $\mathrm{Pb}^{2+}, \mathrm{Cd}^{2+}$, $\mathrm{Cu}^{2+}$, and $\mathrm{Ni}^{2+}$. The adsorption process was governed by the ion-exchange mechanism and electrostatic interactions. Therefore, these novel cellulose-based ion exchange resins could potentially be employed for the removal of heavy metal cations from contaminated wastewaters. Furthermore, these resins are also ecofriendly and relatively low cost.

\section{Acknowledgement}

This research was financially supported by the Department of Materials Science and Engineering, Faculty of Engineering and Industrial Technology, Silpakorn University, Thailand.

\section{References}

1. A. Guleria, G. Kumari, E. Limac, Cellulose-g-poly(acrylamide-co-acrylic acid) polymeric bioadsorbent for the removal of toxic inorganic pollutants from wastewaters, Carbohydrate Polymers, 228, (2020): 115396

2. B. Zhao, H. Jiang, Z. Lin, S. Xu, J. Xie, A. Zhang, Preparation of acrylamide/acrylic acid cellulose hydrogels for the adsorption of heavy metal ions, Carbohydrate Polymers, 224, (2019): 115022

3. Y. Li, Y. Wen, L. Wang, J. He, S. Al-Dey, M. ElNewehy, J. Yue, B. Ding, Simultaneous visual detection and removal of lead(II) ions with pyromellitic dianhydride-grafted cellulose nanofibrous membranes, Journal of Materials Chemistry A, 3, 35(2015): 18180-18189

4. E. Pehlivan, T. Altun, The study of various parameters affecting the ion exchange of $\mathrm{Cu}^{2+}, \mathrm{Zn}^{2+}$, $\mathrm{Ni}^{2+}, \mathrm{Cd}^{2+}$, and $\mathrm{Pb}^{2+}$ from aqueous solution on Dowex 50W synthetic resin, Journal of Hazardous Materials, 134, 1(2006): 149-156

5. A. Demirbas, E. Pehlivan, F. Gode, T. Altun, G. Arslanc, Adsorption of $\mathrm{Cu}(\mathrm{II}), \mathrm{Zn}(\mathrm{II}), \mathrm{Ni}(\mathrm{II}), \mathrm{Pb}(\mathrm{II})$, and $\mathrm{Cd}(\mathrm{II})$ from aqueous solution on Amberlite IR120 synthetic resin, Journal of Colloid and Interface Science, 282, 1(2005): 20-25

6. S. Edebali, E. Pehlivan, Evaluation of chelate and cation exchange resins to remove copper ions, Powder Technology, 301, (2016): 520-525

7. C. Dong, H. Zhang, Z. Pang, Y. Liu, F. Zhang, Sulfonated modification of cotton linter and its application as adsorbent for high-efficiency removal of lead(II) in effluent, Bioresource Technology, 146, (2013): 512-518

8. C. Dong, F. Zhang, Z. Pang, G. Yang, Efficient and selective adsorption of multi-metal ions using sulfonated cellulose as adsorbent, Carbohydrate Polymers, 151, (2016): 230-236

9. H. Chen, Y. Cheng, Z. Zhu, H. He, L. Zhang, N. Li, Y. Zhu, Adsorption of $\mathrm{Pb}(\mathrm{II})$ from Aqueous Solution by Mercerized Moso Bamboo Chemically Modified with Pyromellitic Dianhydride, Journal of Environmental Engineering, 146, (2020): 04019127

10.P. Prasannam, Removal of heavy metals from solution using ion exchangers based on hydroxyl cellulose, Materials Science and Engineering, 1, (2004): 30-43

11. V. Kumar, A. Kumar, S.K. Singh, M. Kumar, S. Kumar, D. Kumar, R. Singh, Chelating Drug Therapy, Austin Journal of Genetics and Genomic Research, 2, 1(2015): 1-3

12. K.H. Hong and G. Sun, Photoactive antibacterial cotton fabrics treated by $3,3^{\prime}, 4,4^{\prime}$ benzophenonetetracarboxylic dianhydride, Carbohydrate Polymers, 84, 3(2011): 1027-1032 
13. A. Hou, G. Sun, Multifunctional finishing of cotton fabrics with 3,3',4,4'-benzophenone tetracarboxylic dianhydride: Reaction mechanism, Carbohydrate Polymers, 95, 2(2013): 768-772

14. S. Das, A. Bhattachary, S. Haldar, A. Ganguly, S. Gud, Y.P. Tinga, P.K. Chatterjee, Optimization of enzymatic saccharification of water hyacinth biomass for bio-ethanol: Comparison between artificial neural network and response surface methodology, Sustainable Materials and Technologies, 3, (2015): $17-28$

15. A. Ganguly, S. Das, A. Bhattacharya, A. Dey, P. K. Chatterjee, Enzymatic hydrolysis of water hyacinth biomass for the production of ethanol: optimization of driving parameters, Indian journal of experimental biology, 51, (2013): 556-566

16. T. Pusic, A.M. Grancaric, I. Soljacic, V. Ribitsch, The effect of mercerisation on the electrokinetic potential of cotton, Coloration Technology, 115, 4(1999): 121-124

17. B. Abderrahim, E. Abderrahman, A. Mohamed, T. Fatima, T. Abdesselam, O. Krim, Kinetic thermal degradation of cellulose, polybutylene succinate and a green composite: Comparative Study, World Journal of Environmental Engineering, 3, 4(2015): 95-110

18. K. Das, P. Ghosh, A. Dey, A. Ganguly, S. Das, P. K. Chatterjee, Studies on the Optimization of Phenolics during Production of Xylitol from Water Hyacinth, European Journal of Biotechnology and Bioscience, 3, 4(2015): 25-33

19. N. Atikah, M. Nor, W. Aida, W. Mustapha, O. Hassan, Deep Eutectic Solvent (DES) as a Pretreatment for Oil Palm Empty Fruit Bunch (OPEFB) in Sugar Production, Procedia Chemistry, 18, (2016): 147-154

20. D. Gaspar, S.N. Fernandes, A.G. de Oliveira, J. G. Fernandes, P. Grey, R.V. Pontes, L. Pereira, R. Martins, M.H. Godinho, E. Fortunato, Nanocrystalline cellulose applied simultaneously as the gate dielectric and the substrate in flexible field effect transistors, Nanotechnology, 25, (2014): 094008

21. I. Kavianinia, P.G. Plieger, N.G. Kandile, D.R.K. Hardinga, New hydrogels based on symmetrical aromatic anhydrides: Synthesis, characterization and metal ion adsorption evaluation, Carbohydrate Polymers, 87, 1(2012): 881-893

22. A. Tripathi, G.N. Parsons, O.J. Rojas, S.A. Khan, Featherlight, Mechanically Robust Cellulose Ester Aerogels for Environmental Remediation, ACS Omega, 2, 8(2017): 4297-4305

23. F. Afinjuomo, T.G.Barclay, Y. Songa, A. Parikh, N. Petrovsky, S. Garg, Synthesis and characterization of a novel inulin hydrogel crosslinked with pyromellitic dianhydride, Reactive and Functional Polymers, 134, (2019): 104-111

24. G. Luo, P.J. Strong, H. Wang, W. Ni, W. Shi, Kinetics of the pyrolytic and hydrothermal decomposition of water hyacinth, Bioresource Technology, 102, 13(2011): 6990-6994

25. M.G. Junior, K.M. Novack, V.R. Botaro, Bamboo pulp treated with $\mathrm{NaOH}$ and benzophenone tetracarboxylic dianhydride as reinforcement of new polymerics materials, Revista Latinoamericana de Metalurgia y Materiales, 34, 2(2013): 196-208

26. Y. Zhang, M. Zhang, Y. Zhang, X.W. Chen and J. H. Wang, Green and catalyst-free preparation of triazinyl polyimide for the efficient adsorption of glycoproteins, RSC Advances, 6, 51(2016): 4600246007

27. T.T. Hong, H. Okabe, Y. Hidaka, B.A. Omondi, K. Hara, Radiation induced modified CMC-based hydrogel with enhanced reusability for heavy metal ions adsorption, Polymer, 181, (2019): 121772

28. M. Maslova, V. Ivanenko, N. Yanicheva, L. Gerasimova, The effect of heavy metal ions hydration on their sorption by a mesoporous titanium phosphate ion-exchanger, Journal of Water Process Engineering, 35, (2020): 101233

29. S. Huang, C. Min, Y. Liao, H. Sun, Y. Jiang, Poly(1amino-5-chloroanthraquinone): Highly selective and ultrasensitive fluorescent chemosensor for ferric ion, Journal of Fluorescence, 23, (2013) :621-627

30. E. R. Nightingale, Phenomenological Theory of Ion Solvation: Effective Radii of Hydrated Ions, The Journal of Physical Chemistry, 63, 9(1959): 13811387

31. Sigma Aldrich Co.,Ltd, Cation exchange resin, June 25, (2021), Available from https://www.sigma aldrich.com/TH/en/search/cation-exchange-resin 